\title{
Relying on "Integral Body Multi Wing" Personnel Training Mode to Improve the Quality of Undergraduate Education
}

\author{
Jing-Feng HE \\ College of Control Engineering, Xijing University, Xi' an 710123, China \\ 573825625@qq.com
}

Keywords: Integral body multi wing, Innovation and Entrepreneurship, Training model, General Education

\begin{abstract}
Under the context of mass higher education, the research achievements of the undergraduate application-oriented talent cultivation mode reform have sprung up. These achievements clarify such concepts as the application- oriented talent and talent cultivation mode, and a practical research in the undergraduate application-oriented talent cultivation mode construction has been conducted. However, the current research is still insufficient. The research of the social needs for application-oriented talents should be strengthened, and the reform in undergraduate talent cultivation standards and mode should be studied; in order to develop a talent cultivation program consistent with the university's own characteristics, and to increase the quality of the application-oriented talents cultivation. This paper puts forward a kind of "Integral body multi wing" talent training mode based on the improvement of college students' comprehensive ability.
\end{abstract}

\section{Introduction}

Application oriented personnel training goal orientation, and actively explore the new model of personnel training. Through years of exploration and practice gradually formed "the spirit of science, humanities literacy, professional expertise" of innovative talents training mode, and on this basis, actively build the personality education and "science + art" to refer to the guiding ideology of "integral body multi wing" talent training mode. "integral body multi wing" talent training mode is through diversified construction, diversified and three-dimensional learning resource platform, to provide students personalized, differentiated, customized education services, while students carry out the provisions of the contents of learning, choose a full range carry out selective, independent learning, to achieve the aim of personalized learning, diverse culture and a strong professional ability, great personality, and finally work as personalized technology.

"Integral body multi wing" talent training mode is to combine the ability training with the project teaching; establish discipline competition platform, school-enterprise cooperation platform, social practice platform, strengthen the International exchange program, create innovation and entrepreneurship education practice base, to provide students with personalized, differentiated, customized education services, enhance the comprehensive quality of students and employment and entrepreneurship, training innovative application-oriented professionals to meet the needs of the community.

\section{Problems existing in the cultivation of students' innovation ability in our country}

At the third session of the second session of the National People's Congress on March, 05, 2015, the Premier Li Keqiang regarded "promoting public venture" as an effective way to cultivate the economic and social development of new power in an effective way. The report pointed that "which can both expand employment, increase the income of residents and conducive the promotion of social vertical mobility and justice... Individuals and enterprises should be bold in innovation; it's the duty for the whole society to build innovation culture, so that the folks could achieve spirit success and their own value with the progress of creating wealth ${ }^{[1]}$.

The leader with high-tech knowledge is an indispensable part for entrepreneurial innovation, the university is the main force of innovation and entrepreneurship, students and graduate students group 
At present universities exist a common phenomenon in the process of college students cultivating, "five weigh and five light", which is: emphasizing theoretical teaching while despising practical teaching; emphasizing knowledge teaching while despising ability teaching; emphasizing uniform requirements while despising personality development; emphasizing intellectual factors while despising non-intellectual factors training; emphasizing basic knowledge and basic skills training while despising cultivating creative thinking ability, etc. "five light" is a defect of talent cultivation in colleges and universities. To solve the problems existing in the talent training scheme, according to the talents training mode "Integral body multi wing" in the talent training scheme to revise, "Integral body multi wing" training mode is shown in Fig. 1. A scheme of talent cultivation target is more accurate, pay attention to improve students' comprehensive quality and practice ability and the cultivation of innovation spirit and the fabric of the training scheme of course system, teaching content of planning and hours, credit allocation of scientific and reasonable, in line with the training target and the rule of the students' career development.

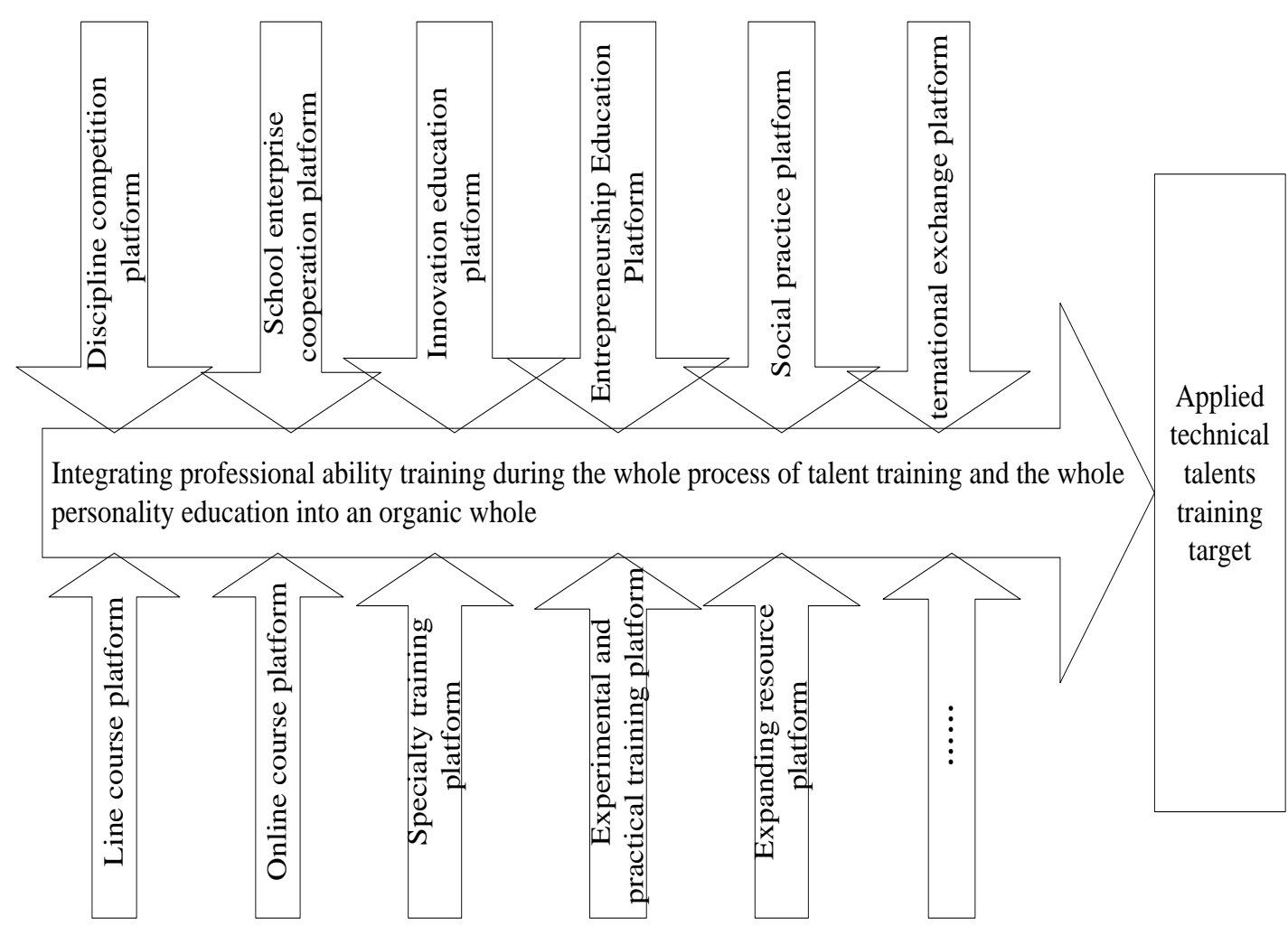

Fig. 1 Integral Body Multi Wing training mode

\section{Relying on "Integral body multi wing" personnel training mode to modify the curriculum system}

"Integral body multi wing" personnel training model curriculum system as shown in table 2. 
Table 2 "Integral body multi wing" personnel training model curriculum system

\begin{tabular}{|c|c|c|c|c|c|}
\hline $\begin{array}{l}\text { Category } \\
\text { don't }\end{array}$ & \multicolumn{3}{|l|}{ Content of courses } & $\begin{array}{l}\text { Course } \\
\text { nature }\end{array}$ & $\begin{array}{l}\text { Proportion } \\
\text { of credits }\end{array}$ \\
\hline \multirow{2}{*}{$\begin{array}{l}\text { General } \\
\text { Education } \\
\text { ( } 58 \text { credits) }\end{array}$} & \multicolumn{2}{|c|}{ Public class must (about 44 units) } & $\begin{array}{l}\text { The main courses includes } \\
\text { English, computer, etc. }\end{array}$ & Required & \\
\hline & \multicolumn{2}{|c|}{$\begin{array}{l}\text { The public elective course (about } 14 \\
\text { units) }\end{array}$} & $\begin{array}{l}\text { Mainly related to the hu- } \\
\text { manities, social sciences, } \\
\text { natural sciences, etc. }\end{array}$ & $\begin{array}{l}\text { Limited } \\
\text { selection }\end{array}$ & $\approx 34 \%$ \\
\hline \multirow{3}{*}{$\begin{array}{l}\text { Professional } \\
\text { education } \\
\text { (65 credits) }\end{array}$} & \multicolumn{2}{|c|}{ Professional foundation platform } & $\begin{array}{l}\text { Course basic courses, pro- } \\
\text { fessional courses }\end{array}$ & Required & \multirow{3}{*}{$\approx 38 \%$} \\
\hline & \multicolumn{2}{|c|}{ Professional core modules } & $\begin{array}{l}\text { Curriculum group for typical } \\
\text { work tasks }\end{array}$ & Required & \\
\hline & \multicolumn{2}{|c|}{ Professional development module } & $\begin{array}{l}\text { Vocational qualifications, } \\
\text { labor skills and other devel- } \\
\text { opment courses }\end{array}$ & $\begin{array}{l}\text { Limited } \\
\text { selection }\end{array}$ & \\
\hline \multirow{3}{*}{$\begin{array}{l}\text { Practice } \\
\text { education } \\
\text { ( } 49 \text { credits) }\end{array}$} & \multirow{2}{*}{$\begin{array}{l}\text { Concentrated edu- } \\
\text { cation practice ( } 45 \\
\text { credits) }\end{array}$} & $\begin{array}{l}\text { General } \\
\text { education } \\
\text { practice } \\
\text { (5 credits) } \\
\end{array}$ & $\begin{array}{l}\text { Entrance education, military } \\
\text { training, public welfare } \\
\text { work, etc. }\end{array}$ & Required & \multirow{3}{*}{$\approx 28 \%$} \\
\hline & & $\begin{array}{l}\text { Practice of } \\
\text { professional } \\
\text { education } \\
\text { ( } 40 \text { credits) }\end{array}$ & $\begin{array}{l}\text { Cognitive practice, curricu- } \\
\text { lum design, professional } \\
\text { practice, graduation practice, } \\
\text { graduation design (Thesis), } \\
\text { etc. }\end{array}$ & Required & \\
\hline & $\begin{array}{l}\text { Comprehensive } \\
\text { educational prac- } \\
\text { tice }(4 \text { credits })\end{array}$ & $\begin{array}{l}\text { Social prac- } \\
\text { tice module } \\
\text { ( } 4 \text { credits) }\end{array}$ & $\begin{array}{l}\text { Community activities, social } \\
\text { surveys and summer social } \\
\text { practice, public welfare } \\
\text { activities, etc. }\end{array}$ & Required & \\
\hline total & \multicolumn{4}{|l|}{ About 172 credits } & $100 \%$ \\
\hline
\end{tabular}

\subsection{General Education}

\section{(1) Compulsory courses in general education}

Compulsory courses in general education are divided into Ideological and political courses, tools, curriculum, physical education courses, employment and entrepreneurship courses. Each teaching unit can be based on professional quality training needs, the need to add the necessary courses.

\section{(2) General education and General Education Elective Course}

Through general education must pass the general education elective through general education elective courses is by the students according to their own needs and independent of the choice of courses, a total of eight categories, each class contains a number of courses, requiring each student to take at least 14 credits. General learning methods can be combined with online teaching resources under the line ${ }^{[5]}$.

\subsection{Professional education}

Professional education curriculum system should be determined according to the requirements of professional post ability. Professional core courses (Group) building ideas should be: clear the corresponding professional post group, to tease out the typical tasks, the typical task of vocational ability analysis and induction, finally mapped into course (Group) ${ }^{[6]}$.

\section{(1) Professional basic courses}

Professional basic courses are based on professional training objectives and requirements, training students' professional basic theory, basic knowledge, basic skills, professional basic ability of the course. Including basic courses and professional courses.

\section{(2)Professional core module}

Professional core curriculum is the core of professional orientation and highlights the professional nature of the curriculum. Set up professional core courses (Group) according to the needs of social development and professional needs, to achieve curriculum (Group) and the typical task of docking, curriculum content and specific business (flow) docking. Depending on the actual situation, each professional can set one or more professional direction. 


\section{(3)Professional development module}

According to the characteristics of the subject, set up the development course, to help students to obtain professional qualifications related to the professional certificate, skills, etc., training students with strong professional skills and professional skills.

\subsection{Practice education}

\section{(1)Concentrated education practice}

The aim is to cultivate students' practical ability and the ability to solve practical problems. The content includes general education practice and professional education practice.

\section{(2)Comprehensive educational practice}

Practice of comprehensive education mainly refers to the "Ideological and political course" social practice, including social survey, production labor, voluntary service, public welfare activities, science and technology invention and work for student and other social practice activities.

\section{Conclusion}

"Integral body multi wing" talent training model for application oriented college students based is not solid, characteristics of the foundation is thin, to set up the innovation and entrepreneurship courses, students can according to their own interests to choose courses, aims to cultivate the consciousness of innovation and entrepreneurship ${ }^{[7]}$.That includes professional quality and employment ability, teamwork and leadership, entrepreneurship and innovation marketing ability, business negotiation and execution ability, social etiquette and speech ability, foreign language use and communication skills, information processing and solving ability and career planning and self-management ability etc.

\section{References}

[1] Liu hong. "Under the background of public entrepreneurship, innovation and peoples improve the creativity of College Students' practice ability training mode of exploration [J]. Hebei Enterprises, 2016 (1): 69-71.

[2] Zeng Qingjun,Zeng Xiaosong. In cultivating college students ability of practice and innovation oriented multi-level full range of discipline competition system construction and practice [J]. Journal of Chongqing Technology and Business University (Natural Science Edition), 2012 (4): 101-106.

[3] Hong Yu,Zhong Binglin,Zhao Yingsheng,Zhang Xiaoqian.The History, Current Issues and Reform Orientation of China's Graduate Education[J]. China's higher education research, 2012 (7): 41- 46.

[4] Lujing.Exploration of improving the quality of graduation design in Colleges and Universities[J].University Education,2014(1):37-42.

[5]Guo Ming, Zhang Jinfeng, Liaozhong Wu. Research on the mechanism of graduate education to promote undergraduate talents training[J].Higher agricultural education,2009(6):66-71.[6] Li Jianhong. Research on the reform of college graduation design in the transformation period [J].Heilongjiang Education (Higher Education Research \& Appraisal), 2016(2):39-40.

[7]Wang Dongqiang, Chen Tianpei, Wang Aizhong. The Analysis on the Teaching Reform of Applied Innovative Talents Training in University[J].Shandong Higher Education ,2014(3):63-73. 